\title{
MODELING ISOSTERIC HEAT OF SOYA BEAN FOR DESORPTION ENERGY ESTIMATION USING NEURAL NETWORK APPROACH
}

\author{
Reza Amiri Chayjan ${ }^{1 *}$, and Mahmood Esna-Ashari ${ }^{1}$
}

\begin{abstract}
Sorption isotherm of soya bean (Glycine $\max$ (L.) Merr.) was obtained by the dynamic experimental method. Artificial Neural Networks (ANNs) were used for modeling soya bean equilibrium moisture content (EMC). Thermodynamic equations and trained ANN for prediction of two thermodynamic properties of net isosteric heat and entropy of soya bean were utilized. The ANN models were better compared with mathematical models. In this study, the isosteric heat and entropy of sorption of soya bean were separately predicted by two power models as a EMC function. Predictive power of the models was high $\left(\mathrm{R}^{2} \approx 0.99\right)$. At the moisture content above $11 \%$ (dry basis, db), isosteric heat and entropy of sorption of soya bean were smoothly decreased, while they were highest at moisture content about $8 \%$ (db). Isosteric heat and entropy would be useful in the storage simulation of dried soya bean. The ANN model predicts soya bean EMC more accurately than mathematical models. Hence, better equations could be developed for the prediction of heat of sorption and entropy based on data from the ANN model.
\end{abstract}

Key words: Back propagation, entropy, isosteric heat, sorption isotherm, soya bean.

\section{INTRODUCTION}

Soya bean (Glycine max (L.) Merr.) is a highly nutritious seed used both as oil and a proteineous seed. Its oil and protein contents range between $13.5-24.2 \%$ and 29.6$50.3 \%$, respectively. The seed of soya bean cv. Pershing contains about $19.4 \%$ oil, $36.2 \%$ protein, $30.45 \%$ carbohydrate, $8.85 \%$ fiber and $5.1 \%$ ash. Post harvest quality of soya bean is very important considering high moisture content of seed at harvesting. Energy consumption of drying process with regard to final moisture content is an index for selection of dryer or drying process. Equilibrium moisture content (EMC), which is defined as the moisture content of a hygroscopic material in equilibrium with a particular environmental condition (temperature and relative humidity), is a vital parameter in studying the drying process. Studies have proved that if the two mentioned environmental factors are not controlled, the mold activities increase (Brooker et al., 1992).

Air temperature and water content of seed affect seed storage life. Increasing these factors causes an

${ }^{1}$ Bu-Ali Sina University, Faculty of Agriculture, Postal Code: 6517833131, Hamedan, Iran.

*Corresponding author (amirireza@basu.ac.ir).

Received: 2 January 2010.

Accepted: 12 October 2010. increase in seed respiration and enzymes production. This phenomenon tends to decrease seed storage and germination (Copeland and McDonald, 1995). EMC is a durability criteria and any change in quality of food and agricultural products during storage and packaging is crucialy important (Veltchev and Menkov, 2000). Fundamental relationship between EMC and relative humidity of food products is known as sorption isotherms (Palipane and Driscroll, 1992). Sorption characteristics of food and agricultural products are used for designing, modeling and optimizing some processes such as drying, aeration and storage (Labuza, 1975; Bala, 1997).

Numerous isotherm models for food have been suggested (Lamauro et al., 1985; Mir and Nath, 1995; Kaymak-Ertekin and Gedik, 2004; Lahsasni et al., 2004; Reddy and Chakraverty, 2004). Of these models, the GAB (Guggenheim, Anderson and de Boer) is the most versatile and widely used model.

Phomkong et al. (2006) fitted the Chung Pfost, Oswin and GAB models to desorption isotherm data of peach, plum and nectarine, and the GAB model was found to give the best data representation. Janjai et al. (2006) determined the isotherm data of longan (Dimocarpus longan Lour.) using dynamic method and fitted data to five selected mathematical models. The GAB model was also found to be the best to fit the experimental isotherm data of longan. 
Isotherms of agricultural products are usually sigmoidshape curves even difficult to draw and manipulate (Bala, 1997). Several complex mathematical models have been developed to describe these curves (Janjai et al., 2006). Non linear direct optimization techniques are required for the estimation of parameters of these models; such estimations limit the accuracy and the shape of the isotherms as well as the reliability of the predictions over the whole range of the relative humidity. Therefore, research is necessary to find alternative computation models calculating the relationship of agricultural product isotherms for increasing accuracy and reliability of predictions. Artificial neural network (ANN) can be an alternative for this purpose.

An artificial neural network consists of neurons, which have been related with special arrangement. Neurons are in layers and every network includes some neurons in input layer, one or more neurons in output layer and neurons in one or more hidden layers. Algorithms and architectures of ANN are different through variation in neuron model and relationship between neurons, and their weights. The learning purpose in ANN is weights updating, so that with presenting set of inputs, desired outputs are obtained. ANNs have been applied on modeling of drying by some workers (Huang and Mujumdar, 1993; Bala et al., 2005; Movagharnejad and Nikzad, 2007; Poonnoy et al., 2007; Lertworasirikul and Tipsuwan, 2008).

Other researchers have used the ANN model for sorption isotherm modeling of black tea (Camellia sinensis L.) and soya bean starch (Pancharyia et al., 2002; Peng et al., 2007). In all of these studies, the ANN models were found to be better than mathematical models.

The net isosteric heat equation is suggested to use in the computation of soya bean heat of sorption, while both the isosteric heat and entropy equations are essential to compute the humidity during simulation of stored dried soya bean. If ANN models are developed using experimental EMC data of soya bean, the developed models can be used to predict the EMC more accurately using computer. This can also be occurred in the accurate predicting of isosteric heat and entropy for modeling and simulation of soya bean drying and storage. The net isosteric heat of sorption is an important parameter for drying and a measure of the water-solid binding strength. It can be used to determine the energy requirements and to show the state of water within the dried material. The moisture content level of a material at which the net isosteric heat of sorption reaches the value of latent heat of sorption, is often considered as the indication of the amount of bound water existing in the material (Wang and Brennan, 1991).

Researchers have proposed an empirical exponential relationship between the net isosteric heat of sorption and material moisture content for some fruits and also a power function between them for pineapple (Ananas comosus (L.) Merr.) (Tsami, 1994; Hossain et al., 2001). The differential entropy of a material is proportional to the number of sites at a specific energy level (Madamba $e t$ al., 1996). Many researchers have found the relationship between net isosteric heat of sorption and moisture content. Madamba et al. (1996) adopted an exponential relation to describe the entropy of garlic sorption as a function of moisture content. McMinn et al. (2004) reported that the net isosteric heat of sorption and differential entropy of potato decreased with increasing moisture content and those were adequately characterized by a power law model. Equation of net isosteric heat of sorption and differential entropy is necessary for modeling and simulation of drying and storage of soya bean.

No study has so far been carried out on the sorption isotherm of soya bean using ANN method. No information about net isosteric heat of sorption and differential entropy models of soya bean (cv. Pershing) is also available. The objectives of this study were to develop an ANN model on experimental data of sorption, an improved empirical model for the net isosteric heat of sorption, and also a new empirical model for the net isosteric heat of entropy for soya bean.

\section{MATERIALS AND METHODS}

\section{Experimental setup and mathematical models}

Soya bean samples (cv. Pershing) were supplied from a farm in the Golestan province, Iran. Salt saturated solutions including $\mathrm{LiCl}, \mathrm{KC}_{2} \mathrm{H}_{3} \mathrm{O}_{2}, \mathrm{MgCl}_{2}, \mathrm{~K}_{2} \mathrm{CO}_{3}, \mathrm{NaBr}$, $\mathrm{NaNO}_{2}, \mathrm{NaCl}, \mathrm{KCl}$ and $\mathrm{K}_{2} \mathrm{SO}_{4}$ (all from Merk, Germany) were used to provide needed relative humidity.

One of the most common methods used for EMC determination is gravimetric, as it has high precision and dose not need a complex implementation (Spiess and Wolf, 1983). Five grams of soya bean kernels were considered as an experimental sample. Each sample was placed into a Petri dish ( $90 \mathrm{~mm}$ in diameter). All dishes were then transferred into a desiccator and kept for $6 \mathrm{wk}$ and weighed every single day. Equilibrium was derived when the difference of any successive weighing was lower than $0.001 \mathrm{~g}$ (Ayranchi et al., 1990; Gabas et al., 1999).

To establish a fix relative humidity at water activity domain of $12-94 \%$, nine salt saturated solutions were utilized. Providing such relative humidity by the saturated solutions has been reported through the literature (Bala, 1997). Besides, these values were also checked using a hygrometer.

The temperature needed for the experiment was provided by the use of an incubator with an electrical 
heater and an electronic temperature controller to maintain the temperature. An electric fan was fitted to circulate the air inside the sample box to accelerate moisture transfer between the samples and air inside the sample box. Four to five weeks were needed for the samples to be reached equilibrium. Lower relative humidity and upper experimental temperature cause a decrease in the time required for the equilibrium. In order to determine the final moisture content, the equilibrated samples were placed in an oven $\left(103{ }^{\circ} \mathrm{C}\right)$ for $72 \mathrm{~h}$. All the experiments were conducted in three replicates.

Five common mathematical models were used for prediction of sorption isotherms in this study as follows:

$$
\begin{aligned}
& E M C=-\frac{1}{C} \ln \left[-\frac{(T+B) \ln a_{w}}{A}\right] \quad \begin{array}{c}
\text { (Modified } \\
\text { Chung-PFost) }
\end{array} \\
& E M C=\left[\frac{-1}{A(T+B)} \ln \left(1-a_{w}\right)\right]^{\frac{1}{C}} \quad \begin{array}{c}
\text { (Modified } \\
\text { Henderson) }
\end{array} \\
& E M C=(A+B T)\left[\frac{a_{w}}{1-a_{w}}\right]^{\frac{1}{C}} \quad \begin{array}{c}
\text { (Modified } \\
\text { Oswin) }
\end{array} \\
& \left.E M C=\left(A B a_{w}\right) \frac{\left(\frac{C}{T}\right)}{\left(1-B a_{w}+\left(\frac{C}{T}\right) B a_{w}\right)\left(1-B a_{w}\right)} \text { GAB }\right) \\
& E M C=\left[\frac{-\ln a_{w}}{\exp (A-B T)}\right]^{\frac{-1}{C}} \quad \begin{array}{c}
\text { (Modified } \\
\text { Halsey) }
\end{array}
\end{aligned}
$$

where $a_{w}$ is water activity; $E M C$ is equilibrium moisture content (dry basis, \%db) and $T$ is absolute temperature (K). $A, B$ and $C$ are constants for different materials calculated by experimental method. Supremacy of each model for prediction of $E M C$ is expressed by two indices of coefficient of determination $\left(R^{2}\right)$, mean relative error $\left(E_{m r}\right)$ and standard error $(S E)$. The fit was performed by nonlinear regression based on the minimization of the squared sum by means of the Statistica 8 software (Stat Soft).

\section{Artificial neural networks modeling}

Feed and cascade forward neural networks are the most common types of ANN (Menhaj, 1998; Jain and Fanelli, 2000). These networks used for prediction of outputs of new unknown patterns. Furthermore, in this research, feed and cascade forward networks as well as several learning algorithms were utilized.

Feed Forward Back Propagation (FFBP) consists of one input layer, one or several hidden layers and one output layer (Heristev, 1998). For learning this network, back propagation (BP) learning algorithm was used. In the case of BP algorithm, the first output layer weights were updated. The weight coefficient was updated by weight values and learning rules. During training this network, calculations were carried out from input of network toward output and values of error were then propagated to prior layers. Cascade Forward Back Propagation (CFBP) is similar to FFBP network in using the BP algorithm for weights updating, but the main symptom of this network is that, each layer neurons relates to all previous layer neurons.

Two training algorithms including LevenbergMarquardt (LM) and Bayesian regulation (BR) back propagation algorithms were used for updating network weights.

Applying the two inputs in all experiments, the EMC value derived for different conditions. Networks with two neurons in input layer (relative humidity and temperature) and one neuron in output layer $(E M C)$ were designed. Figure 1 shows the considered neural network topology and input and output parameters. Boundaries and levels of input parameters are shown in Table 1. Neural network toolbox of Matlab software (The MathWorks Inc., Natick, Massachusetts, USA) was used in this study.

The increasing method was used for selection layers and neurons for evaluation of various topologies. By this method, when the network was trapped into the local minimum, new neurons were gradually added to the network. Various threshold functions were used to reach the optimized status (Demuth and Beale, 2003):

$$
\begin{aligned}
& Y_{j}=\frac{1}{1+\exp \left(-X_{j}\right)} \quad \text { (LOGSIG) } \\
& \begin{array}{cc}
Y_{j}=\frac{2}{\left(1+\exp \left(-2 X_{j}\right)\right)-1} & \text { (TANSIG) } \\
Y_{j}=X_{j} & \text { (PURELIN) }
\end{array}
\end{aligned}
$$

Where $X_{j}$ is the sum of weighed inputs for each neuron in $j^{\text {th }}$ layer and computed as below:

$$
X_{j}=\sum_{i=1}^{m} W_{i j} \times Y_{i}+b_{j}
$$

Where $m$ is number of output layer neurons, $W_{i j}$ is weight of between $\mathrm{i}^{\text {th }}$ and $\mathrm{j}^{\text {th }}$ layers, $\mathrm{Y}_{i}$ is $\mathrm{i}^{\text {th }}$ neuron output and $b_{j}$ is bias of $\mathrm{j}^{\text {th }}$ neuron for FFBP and CFBP networks. Experimental data of 45,55 and $75{ }^{\circ} \mathrm{C}$ were selected for training network with suitable topology and training algorithm. Also data obtained from experiment of $65^{\circ} \mathrm{C}$ were used for testing the trained network.

The following criterion of root mean squared error 


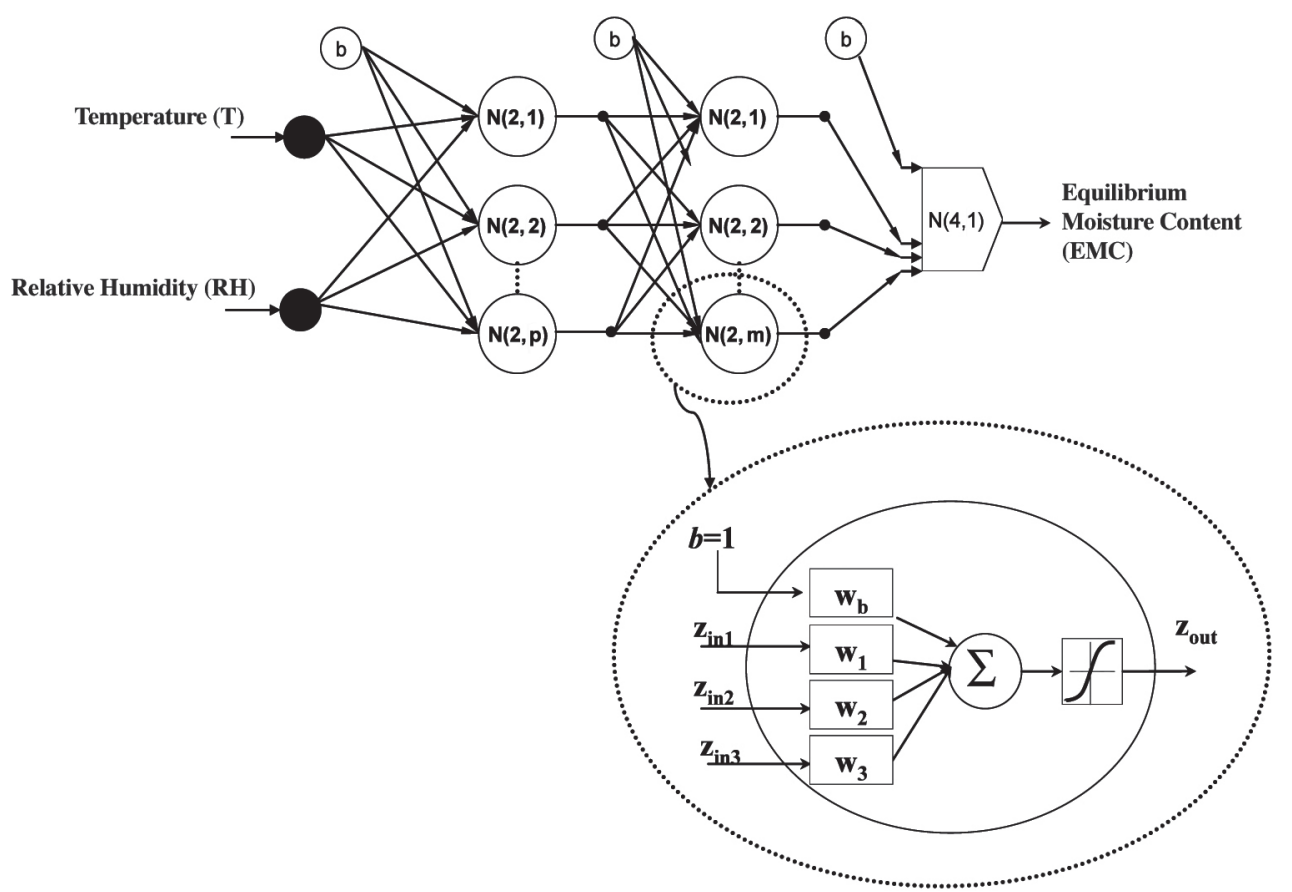

Figure 1. Artificial neural network topology of soya bean equilibrium moisture content.

Table 1. Input parameters for artificial neural networks and their boundaries for the prediction of equilibrium moisture content of soya bean.

\begin{tabular}{lccc}
\hline $\begin{array}{l}\text { Input } \\
\text { parameters }\end{array}$ & $\begin{array}{c}\text { Lower } \\
\text { limit }\end{array}$ & $\begin{array}{c}\text { Upper } \\
\text { limit }\end{array}$ & $\begin{array}{c}\text { Number of } \\
\text { levels }\end{array}$ \\
\hline Air relative humidity, \% & 12 & 94 & 9 \\
Air temperature, ${ }^{\circ} \mathrm{C}$ & 45 & 75 & 4 \\
\hline
\end{tabular}

(RMSE) has defined to minimize the training error (Demuth and Beale, 2003):

$$
\text { MSE }=\sum_{p=1}^{n} \sum_{i=1}^{N}\left(S_{i p}-T_{i p}\right)^{2}
$$

where MSE is the mean squared error, $S_{i p}$ is network output in $\mathrm{i}^{\text {th }}$ neuron and $\mathrm{p}^{\text {th }}$ pattern, $T_{i p}$ is target output at $\mathrm{i}^{\text {th }}$ neuron and $\mathrm{p}^{\text {th }}$ pattern, $N$ is number of output neurons and $M$ is number of training patterns. To optimize the selected network from prior stage, the secondary criteria were used as follow:

$$
\begin{gathered}
R^{2}=1 \frac{\sum_{k=1}^{n}\left[S_{k}-T_{k}\right]}{\sum_{k=1}^{n}\left[S_{k}-\frac{\sum_{k=1}^{n} S_{k}}{}\right]} \\
E_{m r}=\frac{100}{n} \sum_{k=1}^{n}\left|\frac{S_{k}-T_{k}}{T_{k}}\right|
\end{gathered}
$$

$$
S E=\sum_{k=1}^{n} \sqrt{\frac{\left(S_{k}-T_{k}\right)^{2}}{d . f}}
$$

where $R^{2}$ is the determination coefficient, $E_{m r}$ the mean relative error, $S E$ the standard error, $S_{k}$ the network output for $\mathrm{k}^{\text {th }}$ pattern, $T_{k}$ the target output for $\mathrm{k}^{\text {th }}$ pattern, $d f$ is degree of freedom and $n$ the number of training patterns. To increase the accuracy and processing velocity of network, input data was normalized at boundary of $[0,1]$.

\section{Sorption parameters of soya bean}

The net isosteric heat of sorption was determined by the Clausius-Clayperon equation (Hossain et al., 2001; Phomkong et al., 2006):

$$
\frac{d \ln \left(a_{w}\right)}{d T}=\frac{\Delta H}{R T^{2}}
$$

where $R H$ is the relative humidity (\%), $T$ is the absolute temperature $(\mathrm{K}), \Delta H$ is the isosteric heat of sorption $(\mathrm{kJ}$ $\left.\mathrm{mol}^{-1}\right), R$ is the universal gas constant $\left(8.315 \mathrm{~kJ} \mathrm{kmol}^{-1}\right.$ $\left.\mathrm{K}^{-1}\right)$.

Integrating Equation [14] and assuming that $\Delta H$ is independent of temperature, gives the Equation [15] as follow:

$$
\ln \left(a_{w}\right)=-\left(\frac{\Delta H}{R}\right) \frac{1}{T}+c
$$

where $C$ is the intercept of the Equation [15]. The value of $\Delta H$ is computed from the slope of the Equation [15]. As 
following relationship in thermodynamic (Rizvi, 1995):

$$
\Delta G=-\Delta H-\mathrm{T} \Delta S
$$

where $\Delta G$ is the Gibbs free energy $\left(\mathrm{J} \mathrm{mol}^{-1}\right)$ and $\Delta S$ is the entropy $\left(\mathrm{J} \mathrm{mol}^{-1} \mathrm{~K}^{-1}\right)$. For moisture sorption, it can be shown that:

$$
\Delta G=-R T \ln \left(a_{w}\right)
$$

Substituting $\Delta G$ from Equation [16] into Equation [17], the following equation is obtained:

$$
-\ln \left(a_{w}\right)=\left(\frac{\Delta H}{R}\right) \frac{1}{T}-\frac{\Delta S}{R}
$$

When $\ln \left(a_{w}\right)$ are plotted against $1 / \mathrm{T}$, a straight line graph is obtained with the $y$-intercept of $\Delta S / R$. From the values of this y-intercept and $R, \Delta H$ and $\Delta S$ can be computed.

\section{RESULTS AND DISCUSSION}

\section{Dehydration curves}

Equilibrium moisture content of soya bean was experimentally determined using a dynamic method. The average of $E M C$ in three replication as well as water activities of salt solutions is shown in Figure 2. These curves are the moisture sorption isotherm of soya bean at four temperature levels of $45,55,65$ and $75^{\circ} \mathrm{C}$ in the range of $12-94 \%$ relative humidity. Increasing temperature in a water activity decreased $E M C$. Increasing water activity caused an increase in soya bean $E M C$ at of all temperatures. This smooth change in all temperatures is obvious and occured because of high density and high oil percentage of soya bean.

\section{Mathematical models}

Five mathematical models were used for soya bean $E M C$ empirical data fitting. Non linear regression method with software was used for fitting the data. Three indices of $\mathrm{R}^{2}, \mathrm{E}_{\mathrm{m}}$ and $S E$ were utilized for appropriate fitness determination.

Results of empirical models fitting at $65{ }^{\circ} \mathrm{C}$ (testing point for comparing two methods) are shown in Table 2. For this temperature, modified GAB model produced the best results, including $R^{2}=0.9662, \mathrm{E}_{\mathrm{mr}}=8.354 \%$ and $S E$ $=1.325$. Therefore, this model is capable of producing the best results for the four temperature levels that could be used for the $E M C$ estimation of soya bean, net isosteric heat of sorption and net isosteric entropy of sorption at various temperatures and water activities. Any empirical model has an equation with constants which are presented in Table 2.

\section{ANN models}

FFBP and CFBP networks were used for mapping between inputs and outputs of patterns. Various compositions of threshold functions were used in layers. Several topologies were tested and the best results that used from each network, training algorithm and threshold functions (Table 3).

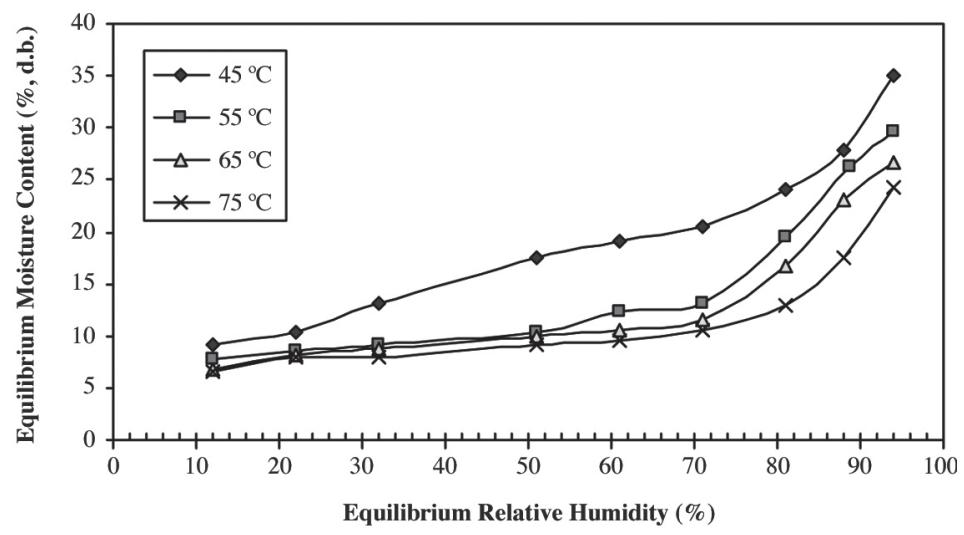

Figure 2. Sorption isotherm of soya bean from the experiments at different temperature levels.

Table 2. Coefficients and outputs of mathematical models for soya bean.

\begin{tabular}{lccccrc}
\hline Model & $\mathbf{A}$ & $\mathbf{B}$ & $\mathbf{C}$ & $\mathbf{R}^{\mathbf{2}}$ & $\mathbf{E}_{\mathbf{m r}}$ & SE \\
\hline Modified Chung-PFost & 187.589 & -297.895 & 0.1925 & 0.9210 & 13.021 & 1.871 \\
Modified Henderson & 0.000055 & -293.158 & 2.43 & 0.8487 & 14.250 & 2.153 \\
Modified Oswin & 62.245 & -0.154 & 3.98 & 0.9412 & 10.895 & 1.887 \\
Modified GAB & 6.3451 & 0.789 & -578146.6 & 0.9662 & 8.354 & 1.325 \\
Modified Halsey & 19.536 & -0.0401 & 2.9874 & 0.9353 & 11.456 & 1.952 \\
\hline
\end{tabular}

$A, B$ and $\mathrm{C}$ are constants for different materials calculated by experimental method; $\mathrm{R}^{2}$ : coefficient of determination; $\mathrm{E}_{\mathrm{mr}}$ : mean relative error; and $\mathrm{SE}$ : standard error. 
Table 3. Training algorithms for different neurons and hidden layers of networks for prediction of soyabean Equilibrium Moisture Content (EMC).

\begin{tabular}{|c|c|c|c|c|c|c|c|c|}
\hline Network & $\begin{array}{l}\text { Training } \\
\text { algorithm }\end{array}$ & Threshold function & $\begin{array}{c}\mathrm{N}^{\circ} \text { of } \\
\text { layers } \\
\text { and } \\
\text { neurons }\end{array}$ & MSE & $\mathbf{R}^{2}$ & $\mathbf{E}_{\mathrm{mr}}$ & SE & Epoch \\
\hline \multirow[t]{2}{*}{ CFBP } & LM & TANSIG-TANSIG-LOGSIG & $2-4-3-1$ & 0.000704 & 0.9963 & 4.521 & 0.785 & 37 \\
\hline & $\mathrm{BR}$ & TANSIG-LOGSIG-PURELIN & $2-3-2-1$ & 0.000883 & 0.9951 & 5.521 & 0.845 & 23 \\
\hline \multirow[t]{2}{*}{ FFBP } & LM & TANSIG-TANSIG-TANSIG & $2-4-2-1$ & 0.000951 & 0.9918 & 7.108 & 0.989 & 38 \\
\hline & $\mathrm{BR}$ & LOGSIG-LOGSIG-PURELIN & $2-3-3-1$ & 0.000923 & 0.9935 & 6.33 & 0.895 & 46 \\
\hline
\end{tabular}

CFBP: Cascade Forward Back Propagation; FFBP: Feed Forward Back Propagation; LM: Levenberg-Marquardt; BP: back propagation; MSE: mean squared error; $\mathrm{R}^{2}$ : coefficient of determination; $\mathrm{E}_{\mathrm{mr}}$ : mean relative error; and $\mathrm{SE}$ : standard error.

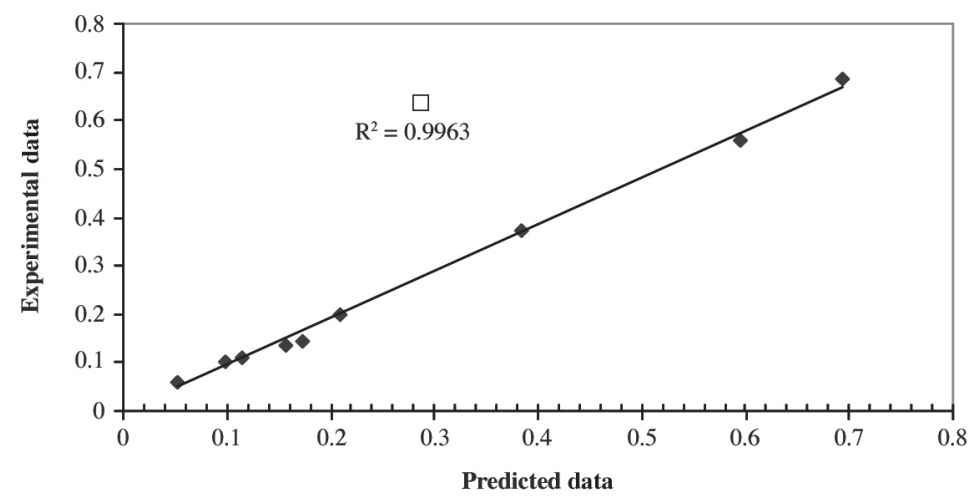

Figure 3. Predicted values of Equilibrium Moisture Content (EMC) using artificial neural networks versus experimental values for testing data set $\left(65^{\circ} \mathrm{C}\right)$.

The best results belonged to CFBP network, TANSIGTANSIG-LOGSIG threshold function and 2-4-3-1 topology. This composition produced MSE $=0.000704$, $R^{2}=0.9963, E_{m r}=4.521$ and $S E=0.785$ converged in 32 epochs. The $R^{2}$ of optimized ANN is plotted in Figure 3.

Comparison of the ANN method and the mathematical model results showed that ANN had the supremacy in EMC prediction for soya bean cv. Pershing. The optimized ANN topology has therefore been used for the prediction of soya bean net isosteric heat and entropy of sorption.

\section{Heat and entropy of soya bean}

Equilibrium moisture contents values of soya bean at the four temperature levels $\left(45,55,65\right.$ and $\left.75{ }^{\circ} \mathrm{C}\right)$ and seven moisture levels $(8,11,14,17,20,23$ and $26 \%)$ were computed using the optimized neural network model. Values of $\ln (\mathrm{RH})$ versus function of $1 /$ Tab were plotted for soya bean 'Pershing' at constant moisture contents (Figure 4). These values were estimated by the optimized ANN. The slope of the lines at constant moisture contents were the net isosteric heat of sorption for soya bean. The slopes were determined by linear regression analysis. The heat of sorption for soya bean at different moisture contents is presented in Figure 5.

The net isosteric heat of sorption was found to be decreased with increasing moisture content at low moisture content. Water was absorbed on the most accessible locations on the exterior surface of the solid. As the moisture content increased the material swell and therefore, new high-energy sites are opened up for water to get bound to. This causes the net isosteric heat of sorption to increase as with moisture content decrease. This trend is similar to those reported for agricultural, food, medicinal and aromatic plants (Lahsasni et al., 2004; Reddy and Chakraverty, 2004; Phomkong et al., 2006). The net isosteric heat of sorption was found to be fitted a power law relation. The following equation was developed for soya bean:

$$
\Delta H=501.09 M C^{-1.4632} \quad R^{2}=0.9865
$$




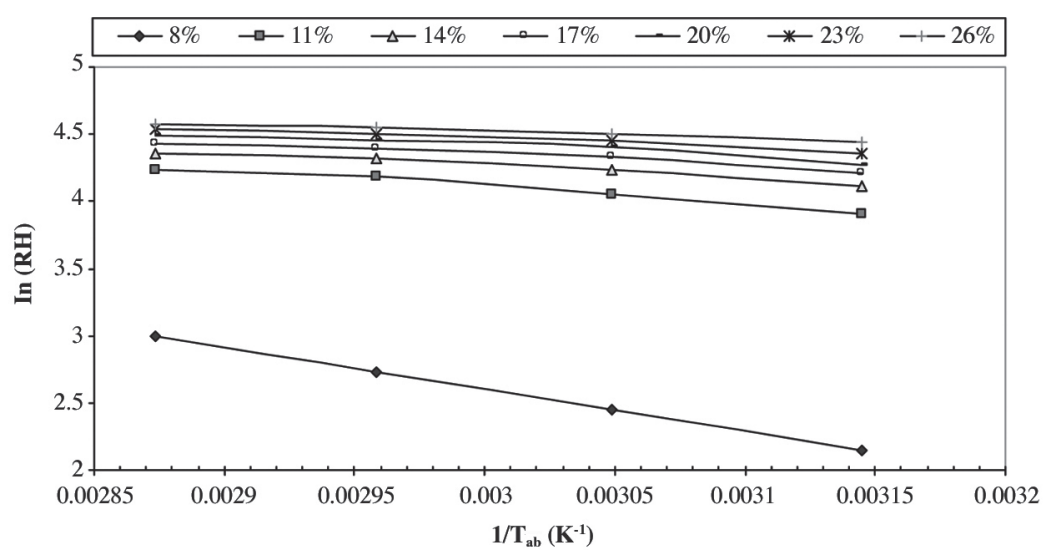

Figure 4. $\ln (\mathrm{RH})$ as a function of $1 / \mathrm{T}$ at different moisture content for soya bean.

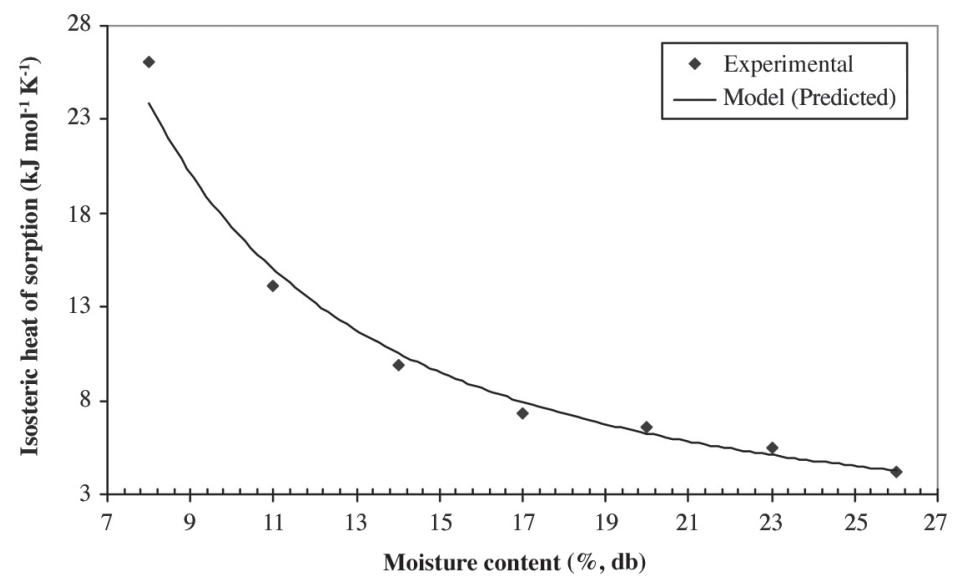

Figure 5. Soya bean isosteric heat of sorption at different equilibrium moisture contents.

This relation showed that the net isosteric heat of sorption for soya bean increases following a power law relationship. This relation has also a better fit than the exponential relation previously developed for Longan (Janjai et al., 2006). The maximum values of isosteric heat of sorption of some agricultural products that reported by researchers have been compared with this study (Table 4). The lower values of soya bean heat of sorption compared to the other agricultural products were due to the differences in the chemical composition and tissues of soya bean. The isosteric heat of sorption of soya bean is significantly high, while its EMC is lower than $11 \%(\mathrm{db})$. This can be explained by the fact that at moisture content above $11 \%(\mathrm{db})$, water is loosely bound in soya bean. This implies that soya bean needs less energy at higher moisture content (above $11 \% \mathrm{db}$ ) for drying but more energy at lower moisture contents, especially for storage. After processing, dried soya bean with $18 \%(\mathrm{db})$ moisture content is stored (Brooker et al., 1992), so results showed that, its isosteric heat at $18 \%(\mathrm{db})$ was placed in a normal range.
Entropy of sorption of soya bean (cv. Pershing) is presented in Figure 6. It is a function of moisture content and the following power law models was fitted to data:

$$
\Delta S=330.04 M C^{-0.6002} \quad R^{2}=0.9809
$$

The fitted curves for prediction of entropy had good values compared to experimental one. These result proved that, the entropy decreases with increase in moisture content. Similar trends have been reported on the entropy of potato tuber and melon seed as well as cassava (Aviara and Ajibola, 2002; McMinn and Magee, 2003).

The derived equations for isosteric heat and entropy of sorption are necessary for calculation of humidity during storage of soya bean. These results showed that the ANN method has supremacy to mathematical models because it provides more accurate data to develop better equations for isosteric heat and entropy of sorption. 
Table 4. The values of isosteric heat for minimum Equilibrium Moisture Content (EMC) in some agricultural products compared with soya bean.

\begin{tabular}{lccl}
\hline Products & $\begin{array}{c}\text { Minimum } \\
\text { EMC }\end{array}$ & $\begin{array}{c}\text { Isosteric heat of } \\
\text { sorption }\end{array}$ & \multicolumn{1}{c}{ Reference } \\
\hline Soya bean (cv. Pershing) & $\%, \mathrm{db}$ & $\mathrm{kJ} \mathrm{mol}^{-1}$ & This study \\
Longan & 8 & 26.07 & Janjai et al. $(2006)$ \\
Litchi & 40 & $\approx 19.5$ & Janjai et al. $(2007)$ \\
Mango & 20 & $\approx 32$ & Janjai et al. $(2009)$ \\
Maize & 30 & $\approx 18$ & Amiri Chayjan and Esna-Ashari (2010) \\
\hline
\end{tabular}

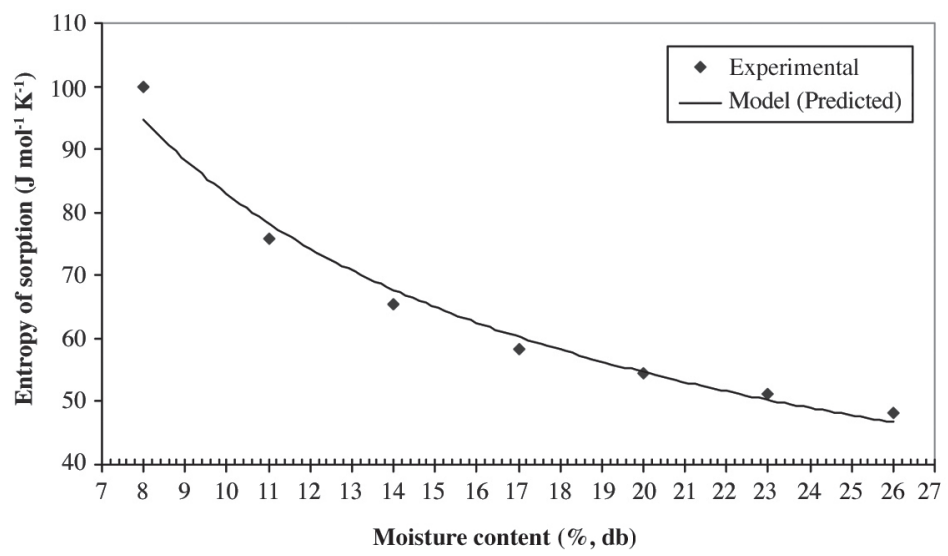

Figure 6. Soya bean entropy of sorption at different equilibrium moisture contents.

\section{CONCLUSIONS}

Application of mathematical models and artificial neural network showed that the artificial neural network has the supremacy in prediction of equilibrium moisture content of soya bean 'Pershing'. Therefore, the optimized ANN topology was used for prediction of soya bean net isosteric heat and entropy of sorption.

Results showed that the relation between moisture content and net isosteric heat and entropy of sorption in soya bean is a power law model. The isosteric heat of sorption of soya bean characterized by a power law model was developed in this study with $R^{2}$ about 0.99 . Entropy of sorption of soya bean was also determined by a power model. The power model for soya bean had $R^{2}$ about 0.99 .

The upper values of soya bean heat of sorption compared to the agricultural products were due to the differences in the chemical composition and tissues of soya bean. The isosteric heat of sorption of soya bean is significantly high, while its equilibrium moisture content is lower than $11 \%(\mathrm{db})$. This can be explained by the fact that at moisture content above $11 \%(\mathrm{db})$ water is loosely bound in soya bean. This implies that soya bean needs less energy at higher moisture content (above 11\% db) for drying and storage, but more energy at lower moisture contents.

\section{RESUMEN}

Modelación de calor isostérico de soya para estimación de energía de desorción usando red neural. La isoterma de desorción de soya (Glycine max (L.) Merr.) se obtuvo por el método experimental dinámico. Se usaron redes neuronales artificiales (ANN) para modelación del contenido de humedad de equilibrio (EMC) de soya. Se utilizaron ecuaciones termodinámicas y ANN dirigidas para predicción de dos propiedades termodinámicas, calor isostérico neto y entropía de soya. Los modelos ANN fueron mejores comparados con modelos matemáticos. En este estudio, el calor isostérico y entropía de absorción de soya fueron predichas separadamente por dos modelos de poder como una función de EMC. El poder predictivo de los modelos fue alto $\left(\mathrm{R}^{2} \approx 0.99\right)$. A un contenido de humedad superior a $11 \%(\mathrm{db})$, el calor isostérico y entropía de absorción de soya fueron ligeramente reducidos, y fueron las más altas a un contenido de $8 \%$ (db). El calor 
isostérico y entropía podrían ser útiles en la simulación del almacenamiento de soya deshidratada. El modelo ANN predice EMC de soya más confiablemente que los modelos matemáticos. Por lo tanto, podrían desarrollarse mejores ecuaciones para la predicción del calor de absorción y entropía basada en datos del modelo ANN.

Palabras clave: propagación de vuelta, entropía, calor isostérico, isoterma de absorción, soya.

\section{LITERATURE CITED}

Amiri Chayjan, R., and M. Esna-Ashari. 2010. Modeling of heat and entropy sorption of maize (cv. Sc704): Neural network method. Research in Agricultural Engineering (In press).

Aviara, N.A., and O.O. Ajibola. 2002. Thermodynamics of moisture sorption in melon seed and cassava. Journal of Food Engineering 55:107-113.

Ayranchi, E., G. Ayranchi, and Z. Dogantan. 1990. Moisture sorption isotherms of dried apricot, fig and raisin at $20^{\circ} \mathrm{C}$ and $36{ }^{\circ} \mathrm{C}$. Journal of Food Science 55:1591-1593.

Bala, B.K. 1997. Drying and storage of cereal grains. Oxford \& IBH Publishing, New Delhi, India.

Bala, B.K., M.A. Ashraf, M.A. Uddin, and S. Janjai. 2005. Experimental and neural network prediction of the performance of the solar tunnel dryer for drying of jackfruit bulbs and jackfruit leather. Journal of Food Process Engineering 28:552-566.

Brooker, D.B., F.W. Bakker-Arkema, and C.W. Hall. 1992. Drying and storage of grain and oilseeds. AVI Publications, New York, USA.

Copeland, L.O., and M.B. McDonald. 1995. Seed science and technology. Chapman and Hall, New York, USA.

Demuth, H., and M. Beale. 2003. Neural network toolbox for Matlab- Users Guide Version 4.1. The Mathworks, Natrick, Massachusetts, USA.

Gabas, A.L., J. Telis-Romero, and F.C. Menegalli. 1999. Thermodynamic models for water sorption by grape skin and pulp. Drying Technology 17:961-974.

Heristev, R.M. 1998. The ANN Book. GNU Public License. Available at ftp://ftp.funet.fi/pub/sci/neural/ books/ (accessed 3 April 2005).

Hossain, M.D., B.K. Bala, M.A. Hossain, and M.R.A. Mondol. 2001. Sorption isotherm and heat of sorption of pineapple. Journal of Food Engineering 48:103-107.

Huang, B., and A.S. Mujumdar. 1993. Use of neural network to predict industrial dryer performance. Drying Technology 11:525-541.

Jain, L., and A.M. Fanelli. 2000. Recent advances in artificial neural networks design and applications. CRC Press, Boca Raton, Florida, USA.
Janjai, S., B.K. Bala, K. Tohsing, B. Mahayothee, M. Heawsungcharen, W. Muhlbauer, and J. Muller. 2006. Equilibrium moisture content heat of sorption of longan (Dimocarpus longan). Drying Technology 24:1691-1696.

Janjai, S, B.K. Bala, K. Tohsing, B. Mahayothee, M. Heawsungcharen, W. Muhlbauer, and J. Muller. 2007. Moisture sorption isotherms and heat of sorption of mango (Magnifera India cv. Nam Dok Mai). International Agricultural Engineering Journal 16(34):159-168.

Janjai, S., B.K. Bala, K. Tohsing, J. Muller, and W. Muhlbauer. 2009. Moisture sorption isotherms of litchi. International Journal of Food Properties (In press).

Kaymak-Ertekin, F., and S. Gedik. 2004. Sorption isotherms and isosteric heat of sorption for grapes, apricots, apples and potatoes. LebensmittelWissenschaft und- Technologie 37:429-438.

Labuza, T.P. 1975. Interpretation of sorption data in relation to the state of constituent water. p. 155-72. In Duchworth, R.B. (ed.) Water relations of foods. London Academic Press, London, UK.

Lahsasni, N., M. Kouhila, and M. Mahrouz. 2004. Adsorpion-desorption isotherms and heat of sorption of pickly pear fruit (Opuntia ficus-indica). Energy Conversion and Management 45:249-261.

Lamauro, C.J., A.S. Bakshi, and T.P. Labuza. 1985. Evaluation of food moisture sorption isotherm equations. Part 1. Fruit, vegetable and meat products. LebensmittelWissenschaft und- Technologie 18:111-117.

Lertworasirikul, S., and Y. Tipsuwan. 2008. Moisture content and water activity prediction of semi-finished cassava crackers from drying process with artificial neural network. Journal of Food Engineering 84:6574.

Madamba, P.S., R.H. Driscoll, and K.A. Buckle. 1996. Enthalpy-entropy compensation models for sorption and browning of garlic. Journal of Food Engineering 28:109-119.

McMinn, W.A.M., and T.R.A. Magee. 2003. Thermodynamic properties of moisture sorption of potatoes. Journal of Food Engineering 60:157-165.

McMinn, W.A.M., A.H. Al-Muhtaseb, and T.R.A. Magee. 2004. Moisture sorption characteristics of starch gels. Part II: thermodynamic properties. Journal of Food Process Engineering 27:213-227.

Menhaj, M.B. 1998. Fundamental of artificial neural networks. Amir Kabir University Publishing, Tehran, Iran (In Persian).

Mir, M.A., and N. Nath. 1995. Sorption isotherms of fortified mango bars. Journal of Food Engineering 25:141-150. 
Movagharnejad, K., and M. Nikzad. 2007. Modeling of tomato drying using artificial neural network. Computers and Electronics in Agriculture 59:78-85.

Palipane, K.B., and R.H. Driscroll. 1992. Moisture sorption characteristics of in-shell macadamia nut. Journal of Food Engineering 18:63-76.

Pancharyia, P.C., D. Popovic, and A.L. Sharma. 2002. Desorption isotherm modeling of black tea using artificial neural networks. Drying Technology 20:351362.

Peng, G., X. Chen, W. Wu, and X. Jiang. 2007. Modeling of water sorption isotherm for corn starch. Journal of Food Engineering 80:562-567.

Phomkong, W., G. Srzedninchi, and R.H. Driscoll. 2006. Desorption isotherms of stone fruit. Drying Technology 24:201-210.

Poonnoy, P., A. Tansakul, and M. Chinnan. 2007. Artificial neural network modeling for temperature and moisture content prediction in tomato slices undergoing microwave-vacuum drying. Journal of Food Science 72:42-47.
Reddy, B.S., and A. Chakraverty. 2004. Equilibrium moisture characteristics of raw and parboiled paddy, brown rice and bran. Drying Technology 22:837-851.

Rizvi, S.S.H. 1995. Thermodynamics of food and dehydration. p. 223-309. In Rao, M.A. and S.S.H. Rizvi (eds.) Engineering properties of foods. Marcel Dekker, New York, USA.

Spiess, W.E.L., and W. Wolf. 1983. The results of the COST 90 projects on water activity. p. 65-86. In Jowitt, R. (ed.) Physical properties of foods. Applied Science Publisher, London, UK.

Tsami, E.D. 1994. Net isosteric heat of sorption in dried fruit. Journal of Food Engineering 4:327-335.

Veltchev, Z.N., and N.D. Menkov. 2000. Desorption isotherm of apples at several temperatures. Drying Technology 18:1127-1137.

Wang, N., and J.G. Brennan. 1991. Moisture sorption isotherm characteristics of potatoes at four temperatures. Journal of Food Engineering 14:269282. 